\title{
Fistula Vesiko Vaginalis
}

\author{
Luki Ertandri
}

\begin{abstract}
Abstrak
Latar belakang : fistula vesiko vaginalis merupakan bagian dari fistula vesiko urogenital merupakansuatu keadaan ditandai fistel antara kandung kemih dengan vagina yang menyebabkan rembesan urin keluar melalui vagina.

Kasus : wanita $\mathrm{P} 3 \mathrm{AOH} 3,44$ tahun, datang dengan keluhan terasa rembesan buang air kecil dari kemaluan sejak 3 bulan yang lalu. Keluhan muncul 7 hari setelah menajalani operasi histerektomi 3 bulan yang lalu. Histerektomi dilakukan atas indikasi mioma uteri dilakukan di Rumah Sakit Swasta. Tanda vital dalam batas normal. Pada pemeriksaan inspekulo tampak cairan urin menumpuk di fornix posterior. Dilakukan prosedur tes methylene blue didapatkan hasil positif di puncak vagina anterior 1 fistel dengan ukuran 1-1,5 cm. Pada pasien dilakukan fistulorraphy vesikovagina dengan teknik repair latzko dalam spinal anasthesi.

Pembahasan : Kasus fistula vesiko vaginalis biasa muncul di negara berkembang. Diantara faktor predisposisi adalah disebabkan operasi histerektomi, selain itu trauma persalinan dan komplikasi operasi daerah pelvik. Pemeriksaan Fisik dan pemeriksaan tambahan secara konvensional atau minimal invasif seperti sistoskopi, sistografi menggunakan zat kontras bisa membantu menegakan diagnosa, menentukan lokasi, ukuran dan jumlah fistel. Pembedahan adalah terapi andalan untuk fistula urogenital melalui transvagina atau trans abdomen. Pendekatan terapi tergantung ilmu, pengalaman dan kolaborasi dengan ahli lain bila dibutuhkan.
\end{abstract}

Kata kunci: fistula vesiko vaginalis, histerektomi, latzko

\section{Abstract}

Background : Vesica vagina fistula is a part of urogenital fistula wich condition that present fistula between bladder and vagina and make urine mold through vagina.

Case Report: Woman P3AOH3, 44 years old, admitted with complaining mold of urine from vagina since three months ago after seven days having surgery procedure. Complaint appeared seven days after histerctomi procedure. The procedure do as indication myoma uterus, the procedure has done in Private Hospital. The vital signs are normal. On Per Speculum examination, clearly see there are fluids on fornix posterior. methylene blue tes has proceed and get the positive result. Fistula is at the top anterior of vagina, about 1-1,5 cm. Surgery procedure fistulorraphy vesica vagina with latzko technique under Spinal Anesthesia has performed

Discussion : Vesica vagina fistula usually occur in the development country. Predisposition factors of it caused by histerectomi procedure, besides trauma during labour and complication of pelvic surgery may also too. Physical and additional specific examination conventionally or minimal invasive like cystoscopy, cystography with contrast can obtain diagnose, determine the location, size and number of fistula. Surgery is the mainstay therapy for urogenital fistula through trans vagina or trans abdomen. Approaching depend on knowledge, experience and collaboration with other expert if needed.

Keywords: Vesica vagina fistula, histerectomy, latzko

Affiliasi penulis : Pendidikan Dokter FK UNAND (Fakultas

Kedokteran Universitas Andalas Padang

Korespondensi : Luki Ertandri. Email :lukiertandri@gmail.com Telp: 081277758423 


\section{Pendahuluan}

Fistula vesiko vaginalis merupakan hubungan abnormal antara vesikourinaria dengan vagina yang menyebabkan urin keluar terus menerus melalui vagina. Di Eropa dan Amerika Utara, fistula obstetrik telah ditemukan sejak seratus tahun yang lalu dan mulai menghilang. Umumnya kasus ini merupakan efek samping dari terapi bedah dengan radium dan sinar $x$ yang dalam penatalaksanaan keganasan pada daerah pelvis. Obstetrik fistula muncul akibatkan trauma persalianan yang mengenai 50.000-100.000 wanita setiap tahun secara global. Fistula obstetri merupakan suatu kondisi yang dapat dicegah dan diobati. ${ }^{2,6,10}$

Faktor Predisposisi fistula obstetri kelahiran prematur, akses yang terbatas ke pelayanan obstetri dan malnutrisi. Faktor lain seperti kemiskinan, status sosial, pendidikan yang rendah sehingga penderita tidak memeriksakan diri ke pusat pelayanan kesehatan. Prevalensi paling tinggi terdapat pada masyarakat Afrika dan Asia.WHO memperkirakan ada sedikitnya 2.000.000 wanita hidup dengan fistula obstetri dan bertambah $50.000-100.000$ setiap tahunnya. Wanita-wanita ini membiarkan kondisinya tanpa penanganan dikarenakan beberapa alasan: taraf pendidikan yang rendah bahwa masalah yang mereka hadapi tidak dapat diperbaiki dan jarak yang harus ditempuh untuk mencapai fasilitas. Wanita wanita pada lingkungan yang sama juga tidak memeriksakan keadaan mereka ke pusat pelayanan kesehatan meskipun tersedia layanan kesehatan yang mendukung hal ini disebabkan oleh ketidak mampuan mereka untuk membayar pelayanan kesehatan. Rehabilitasi sosial dari wanita yang telah repair fistula juga termasuk sebuah tantangan, dimana beberapa pasien merupakan wanita miskin, diabaikan suami, atau pasangannya atau malah tidak memiliki kemampuan untuk menghidupi diri sendiri. $^{2,6,10}$

\section{Laporan Kasus}

Seorang wanita $\mathrm{P} 3 \mathrm{~A} 0 \mathrm{H} 3$ usia 44 tahun datang ke poli Obstetri dan Ginekologi sub bagian Uroginekologi RSUP M Djamil Padang pada tanggal 16 Juni 2014 dengan keluhan terasa rembesan buang air kecil dari kemaluan sejak tiga bulan yang lalu. Keluhan dirasakan hilang timbul, berbau pesing. Keluhan muncul tujuh hari setelah operasi histerectomi tiga bulan yang di Rumah Sakit Swasta. Riwayat keputihan ada hilang timbul. Riwayat demam tidak ada. Riwayat nyeri perut bagian bawah tidak ada. Riwayat nyeri buang air kecil tidak ada. Riwayat infeksi saluran kemih berulang tidak ada. Riwayat trauma daerah panggul tidaka ada. Riwayat pengobatan radiasi tidak ada. Riwayat keganasan tidak ada. Pasien mempunyai tiga orang anak, anak pertama berusia 26 tahun, kedua 23 tahun dan ketiga usia 20 tahun. Sebelumnya pasienhisterectomi supravaginal atas indikasi mioma uteri di Rumah Sakit Swasta 3 bulan lalu. Saat kontrol ulang pasien dianjurkan rujuk ahli uroginekologi.

Pemeriksaan status generalis keadaan umum tampak sakit sedang kesadaran komposmentis, frekuensi nafas 18 kali permenit, frekuensi nadi 86 kali permenit, tekanan darah $110 / 70 \mathrm{mmHg}$, Suhu $36,9^{\circ} \mathrm{C}$

Pada pemeriksaan genitalia tampak vulva urethra tenang, tidak ada tanda inflamasi, tidak ada massa, tidak ada laserasi. Dilakukan pemeriksaan inspekulo, tampak liang vagina tenang, tidak ada tanda inflamasi, tidak ada masa, tidak ada laserasi, portio tenang. Tampak cairan urin menumpuk di formix posterior. Dilakukan tes methylen blue, hasil (+) di puncak vagina anterior, ukuran $1-1,5 \mathrm{~cm}$ jumlah fistula satu.

Pada pemeriksaan laboratorium darah lengkap, EKG, Ro thorax didapatkan dalam batas normal.

Pasien didiagnosa kerja dengan fistula vesikovagina. Pasien dirawat di bangsal rawatan Ginekologi, dikonsul ke bagian Penyakit Dalam, bagian Jantung, dan bagian Radiologi untuk toleransi operasi repair. Dilakukan fistulorraphy vesikovagina 
dalam spinal anasthesi, pasien posisi lithotomi, repair dilakukan dengan tehnik latzko. Terapi yang diberikan IVFD RL 8 jam/kolf, injeksi Ceftriaxon 2x1 intravena dengan skin test, selama satu hari. Pasien anjuran rawat selama 14 hari, pemasangan catheter threeway dan perawatan chateter selama 14 hari. Vulva hygine dua kali sehari selama 14 hari. Terapi oral cefixime $2 \times 200 \mathrm{mg}$ peroral, betrix $1 \times 500 \mathrm{mg}$ peroral, asam mefenamat $2 \times 500 \mathrm{mg}$ peroral, vitamin C $1 \times 1000 \mathrm{mg}$ peroral.

Selama perawatan pasien tidak ada deman, tidak ada mual, tidak ada nyeri berkemih tidak ada komplikasi pasca fitulorrhaphy.

Pada hari ke 14 pasca operasi, chateter threeway dilepas. Nyeri tidak ada, demam tidak ada. Pemeriksaan genital luka operasi tenang. Pasien diobservasi selama 2-3 hari, tidak ada rembesan urin dari kemaluan, pasien boleh pulang. Anjuran kontrol tiga minggu pasca rawat inap.

\section{Pembahasan}

Telah dilaporkan satu kasus seorang pasien perempuan 44 tahun dengan diagnosis fistula vesiko vaginalis. Diagnosis ditegakan berdasarkan adanya rembesan urin keluar dari kemaluan. Berbau pesing. Pasien riwayat post operasi histerectomi supravagina atas indikasi mioma uteri tiga bulan yang lalu. Gejala muncul tujuh hari pasca operasi. Penyebab fistula obstetrik sering akibat trauma persalinan, selain itu fistula bisa muncul akibat tindakan histerektomi perabdomen sesuai pada kasus ini.

Klasifikasi fistula urogenital secara umum dikelompokkan dalam empat jenis; vesiko-uterina, vesiko-vaginal, urethro-vaginal dan uretero-vaginal. Fistul bisa muncul di lokasi, jumlah, ukuran tertentu dan penyulit lainnya. Kasus fistula vesikovaginal $75 \%$ muncul akibat komplikasi post histerktomi transabdomen atau transvagina. Fistula bisa menutup spontan bila ukuran kecil, jaringan sekitar yang tenang dan sikatrik minimal. ${ }^{2,6,10}$

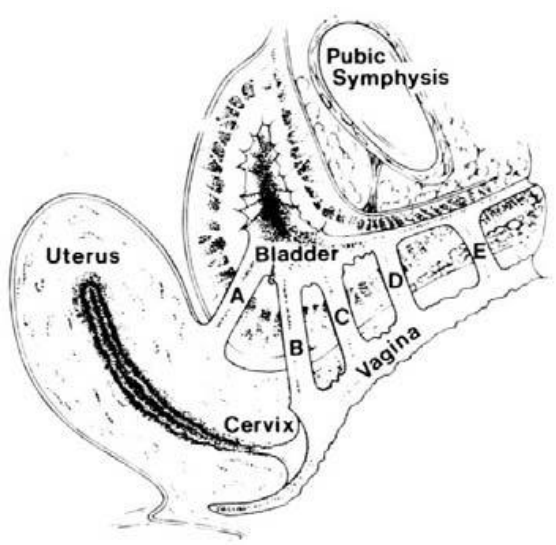

Gambar 1. Klasifikasi fistula

Kriteria diagnostik fistula vesiko vagina dengan mendapatkan anamnesa menyeluruh faktor resiko munculnya fistula, pemeriksaan genital, dan tes diagnostik spesifik. Tes diagnostik menggunakan tes methylen blue, memerlukan beberapa kassa, catheter dan cairan metyhlen blue dengan cairan steril atau salin 0,9\% sebanyak 20-30 cc dimasukan ke buli-buli melalui catheter. Nilai rembesan methylen blue di kassa yang sudah dimasukan kedalam liang vagina. Didapatkan lokasi, ukuran, dan bila mungkin jumlah fistula. ${ }^{1,2,6}$

Jika pemeriksaan ini tidak berhasil, tes diagnostik selanjutnya adalah dengan cara cystoskopi. Kolaborasi pemeriksaan Cystoskopi dilakukan bersama dengan ahli Urologi. Kegunaan Cystoskopi membantu memastikan lokasi anatomis yang pasti dari fistula dan hubungan fistula vesikovagina dengan muara urethra. Pada pasien ini tidak dilakukan karena lokasi yang jelas, ukuran yang cukup besar, tidak multiple, tidak ada penyulit. Pada kasus fistul lebih proksimal atau multiple, melibatkan kandung kemih atau leher kandung kemih dan pada kasus fistula complex yang memerlukan penanganan lebih lanjut, ahli Urogenital Obstetri Ginekologi akan berkolaborasi dengan ahli Urologi. Dan operasi repairdikerjakan bersama. ${ }^{3,5,7}$

Ada beberapa tehnik repair fistula vesiko vagina. Pada pasien ini dilakukan repair fistula dengan menggunakan tehnik latzko dalam spinal anesthesi. Tehnik ini efektif pada fistula vesikovaginal yang berada di puncak vagina. Dengan melakukan exisi cirkular mukosa vagina yang sudah diinfiltrasi 
adrenalin di sekitar muara fistula. Setelah mukosa vagina di exisi, dilakukan penjahitan di muara fistul menggunakan vicril 3.0 tanpa tension, lalu dilakukan penjahitan mucosa vagina. Penjahitan menjadi two layer. Penanganan pasca operasi mempunyai peranan penting. Pengaturan cairan, pemberian analgetik manajemen nyeri, pemasangan threeway catheter selama 14 hari, antibiotik profilak, vulva hygiene, jumlah urin 2-3 Liter dalam satu hari untuk memastikan tidak ada regangan kandung kemih. Pada hari ke 14 pasien anjuran threeway catheter dilepas, dan dalam 2-3 hari tidak ada rembesan urin dari kemaluan, pasien boleh pulang, kontrol tiga minggu post operasi. Pasien dianjurkan tidak coitus selam 2-3 minggu. $^{2,3,5,10}$

Pendekatan pembedahan fistula urogenital dilakukan secara per abdominal atau per vaginam. Hal ini tergantung pada temuan lokasi fistula. Namun pembedahan perabdominal mulai ditinggalkan dengan berkembangnya teknologi lapasrcopic surgery. Penemuan lokasi yang akurat dilakukan dengan menggunakan cystoendoskopi. Fistula yang berada lebih proksimal, melibatkan leher kandung kemih, ureter, jumlah multiple, lokasi yang sulit diidentifikasi akan melibatkan ahli Urologi menggunakan tehnik laparascopic surgery dalam penanganannya.

\section{Daftar Pustaka}

1. Josoprawiro M.J. 2002. Penanganan Fistula Urogenital dengan pendekatan transvagina. urogeniklogi I. Rekonstruksi obstet dan genikol. FK-UI: Jakarta.
2. Junizaf. 2002. Fistula Vesiko Vagina, Urogenikologi I, Uroginikologi Rekontruksi obstet dan genekol. FK-UI : Jakarta.

3. Kohli N, Miklos J.R. 2007. Managing VesicaVagina Fistula, Womens Healt and Education Center- Urogynology : Boston

4. Pranata, A. 2007. Karakteristik Kasus Fistula Urogenital di Departemen Obstetri dan Ginekologi RSUP H. Adam Malik dan RSUD dr. Pirngadi Medan. Tesis. FK-USU : Medan

5. Riley V.J. 2004. Vesikovaginal Fistula, available at Emedicine.

6. Santoso BI. 2002. Fistula Urogenital, Urogenikologi I, Uroginikologi Rekonstruksi Obstet dan ginekol FK-UI : Jakarta.

7. Shobeiri SA, Chesson RR, Echols KT. 2011. Cystoscopy Fistulography: A new technique for the diagnosis of vesikocervical Fistula.

8. Tafesse B, Muleta M, Michael A.W, et al. 2006. Obstetric Fistula and its Physical, Social and Psychological dimension : The Etiopian Scenario. Acta Urologica. 23;4:25-31.

9. Wall L.L, Arrowsmith S.D, Briggs N.D. 2006. Urinary Incotinence in the Developing Word: the Obstetric Fistula, Comittee 12, available at fistulafoundation.org

10. WHO. 2006. Obstetric Fistula.

11. Zmora O, Tulchinsky H, Eyal G, Goldman G, Klauster JM, Rabau M. 2006. Gracilis Muscle Transposition for Fistulas Between the Rectum and Urethra or Vagina. Disease of the Colon and Rectum. 